\title{
Biosynthesis of D-Mannitol by Diplodia pinea
}

\author{
Biossíntese de D-Manitol por Diplodia pinea \\ Biosíntesis de D-Manitol por Diplodia pinea
}

Received: 05/23/2021 | Reviewed: 05/29/2021 | Accept: 06/07/2021 | Published: 06/21/2021

Paula Francislaine Moura

ORCID: https://orcid.org/0000-0003-1617-3144

Universidade Federal do Paraná, Brazil

E-mail: paulafrancislaine19@gmail.com

Caroline Gribner

ORCID: https://orcid.org/0000-0002-0179-1284

Universidade Federal do Paraná, Brazil

E-mail: carol_gribner@yahoo.com.br

Katlin Suellen Rech

ORCID: https://orcid.org/0000-0001-6699-2450

Universidade Federal do Paraná, Brazil

E-mail: katlinrech@gmail.com

Larissa Junqueira Gatto

ORCID: https://orcid.org/0000-0001-6451-7445

Universidade Federal do Paraná, Brazil

E-mail: lari.gatto@gmail.com

Ana Angélica Ruscheweyh Rigoni

ORCID: https://orcid.org/0000-0001-9986-4228

Universidade Positivo, Brazil

E-mail: rigoni.aar@gmail.com

Fernando Cesar Martins Betim

ORCID: https://orcid.org/0000-0002-1668-8626 Universidade Federal do Paraná, Brazil E-mail: fernandobetim@hotmail.com

Ricardo Wagner

ORCID: https://orcid.org/0000-0002-9100-4757 Universidade Federal do Paraná, Brazil

E-mail: ricardo.wagner@ufpr.br

Josiane de Fátima Gaspari Dias

ORCID: https://orcid.org/0000-0002-8548-8505 Universidade Federal do Paraná, Brazil

E-mail: josianefgdias@gmail.com

Obdulio Gomes Miguel

ORCID: https://orcid.org/0000-0002-2231-9130 Universidade Federal do Paraná, Brazil

E-mail: obdulio@ufpr.br

Celso Garcia Auer

ORCID: https://orcid.org/0000-0002-4916-2460 Empresa Brasileira de Pesquisa Agropecuária Florestas, Brazil

E-mail: celso.auer@gmail.com

Marilis Dallarmi Miguel

ORCID: https://orcid.org/0000-0002-1126-9211 Universidade Federal do Paraná, Brazil

E-mail: marilisdmiguel@gmail.com

\begin{abstract}
Research with fungi in search of substances with potential biological activity is gaining more prominence since they are sustainable sources of new molecules. Diplodia pinea is a phytopathogenic fungus found in forest species, which has shown few reports of molecules with biological activity and may present promising biotechnological potential. Thus, the objective of this study was to detect substances produced by this fungus in a liquid medium, under stressful conditions. A metabolite was detected in the alcoholic fraction characterized by X-ray diffraction as D-mannitol. This is the first description of this monosaccharide produced by $D$. pinea.
\end{abstract}

Keywords: Fungi; Metabolites; Carbohydrates; Biotechnology; X-ray diffraction.

\section{Resumo}

As pesquisas com fungos em busca de substâncias com potencial atividade biológica ganham cada vez mais destaque por serem fontes sustentáveis de novas moléculas. Diplodia pinea é um fungo fitopatogênico encontrado em espécies florestais, que tem apresentado poucos relatos de moléculas com atividade biológica e pode apresentar potencial 
biotecnológico promissor. Assim, o objetivo deste estudo foi detectar substâncias produzidas por esse fungo em meio líquido, sob condições de estresse. Um metabólito foi detectado na fração alcoólica e caracterizado por difração de raios-X como D-manitol. Esta é a primeira descrição deste monossacarídeo produzido por D. pinea.

Palavras-chave: Fungos; Metabólitos; Carboidratos; Biotecnologia; Difração de raios X.

\section{Resumen}

La investigación con hongos en busca de sustancias con potencial actividad biológica está ganando más protagonismo ya que son fuentes sostenibles de nuevas moléculas. Diplodia pinea es un hongo fitopatógeno que se encuentra en especies forestales, que ha mostrado pocos informes de moléculas con actividad biológica y puede presentar un potencial biotecnológico prometedor. Así, el objetivo de este estudio fue detectar sustancias producidas por este hongo en un medio líquido, en condiciones de estrés. Se detectó un metabolito en la fracción alcohólica caracterizada por difracción de rayos X como D-manitol. Ésta es la primera descripción de este monosacárido producido por $D$. pinea.

Palabras clave: Hongos; Metabolites; Carbohidratos; Biotecnología; Difracción de rayos X.

\section{Introduction}

It is well established that fungi have been demonstrated great environmental impact, wide diversity, and nature's distribution (Pinto et al., 2002; Rani et al., 2017; Yunes e Calixto 2001). Researches on the biosynthesis potential in molecules from fungi stand out due to the scarcity of studies in biotechnology in sustainable development, which might be considered a promising alternative in the chemical synthesis of molecules. Furthermore, fungi may suffer interference from other organisms or under different stress conditions, altering their metabolic pathway by producing different molecules (Kusari et al., 2013).

Diplodia pinea (D.pinea) is described as a pathogenic fungus capable of causing dieback, cankers, and tree death, in different Pinus species (Reglinski et al., 2013). The high incidence and severity of infection by D. pinea is associated with the spread of its spores by the action of rain and wind, in addition to being endophytic (asymptomatic condition) and transmitted by seedlings. Besides, these fungi have become more aggressive under periods of plant stress (drought, excessive rain, hail, or some injury to the plant) (Reglinski et al., 2013; Smith et al., 2014).

Carbohydrates, as energy suppliers for the survival of fungi, have scientific and technical interest for the input industry. Several studies indicate that these metabolites have demonstrated important biological activities such as antineoplastic, antiviral, and antifungal (Appelt et al., 2013). Thus, monosaccharides can be defined as simple carbohydrate units. These compounds are not polarized, do not undergo hydrolysis, and have a functional group which classifies them as ketosis or aldoses. Its configuration can be assigned to the D or L series depending on the chiral center of the molecule. Besides, the cyclization process can be stabilized in a carbohydrate molecule, giving rise to a ring, being called pyranoses (heterocyclic with 5 carbon atoms and 1 atom of oxygen attached to anomeric carbon) or furanoses (heterocyclic with 4 carbon atoms and 1 atom of oxygen linked to anomeric carbon), depending on the number of carbons present in the chemical structure (Bubb 2013; Fontan and Amadio 2015). Among the monosaccharides which can be obtained from natural sources, mannitol stands out due to its numerous applications. In clinical therapy, it is widely used because it is a potent osmotic diuretic; thus in the food and pharmaceutical industry, it has shown applicability due to its sweetening potential, low hygroscopicity and in chemical synthesis, its chirality allows the potential use of this metabolite in the synthesis of asymmetric catalysis reaction ligands (Oliveira et al., 2009).

In light of the aforementioned, this study aimed to improve the cultivation and characterize chemically a product obtained for the first time from $D$. pinea, evaluate the preliminary toxicity in vitro, and collaborate for the description of physical and chemical parameters of the studied fungus. 


\section{Methodology}

\subsection{In vitro production of fungus}

The isolate of $D$. pinea was obtained from a Pinus taeda tree with dieback, in a commercial plantation located at São José do Ouro/RS/Brazil, 2746'18" S; 51³6'14" W. After isolation in potato-dextrose-agar culture medium - PDA (commercial extract $39 \mathrm{~g}$, ultra-purified water, $1000 \mathrm{~mL}$ ), the fungus was preserved in test tubes with PDA medium and mineral oil at $4{ }^{\circ} \mathrm{C}$ in the Collection of Forest Fungi and Oomycetes from Embrapa Florestas, Colombo/PR, Brazil. A sample of the fungus was deposited in the herbarium of the State University of the West of Paraná - UNIOESTE (exsiccata UNOP 4242) and access register Sisgen $N^{\circ}$ A80029B.

For the production of pure cultures, in a laminar flow hood, the fungus was removed from the mineral oil, with the help of a bacteriological loop and inoculated into Petri dishes containing PDA medium. The plates were incubated in a BOD chamber at $24{ }^{\circ} \mathrm{C}$, in the dark, for 10 days (Silva et al., 2018).

The production of fungal biomass was carried out by inoculating two mycelium agar discs (5 mm) from a pure culture of the fungus, in a laminar flow hood, in glass flasks containing $50 \mathrm{~mL}$ of potato dextrose broth - PD (commercial extract, $27 \mathrm{~g}$, water ultra-purified, $1000 \mathrm{~mL})$, previously autoclaved $\left(20 \mathrm{~min}, 120^{\circ} \mathrm{C}\right)$. The incubation was carried out in a BOD (incubator greenhouse with oxygen demand) chamber at $16^{\circ} \mathrm{C}$, in the dark, for 7 days, without mechanical aeration $($ Moura 2017). After the incubation period, the characteristics of the produced mycelium were observed. The culture broth was evaluated for odor, color, and turbidity, to guarantee the inoculum purity and the absence of contamination. At the end of this process, the mycelial mass was separated from the culture medium by filtration with the aid of a sieve in a laminar flow hood. The fungal biomass was placed in a freezer and after freezing, lyophilized for 5 days at $-80{ }^{\circ} \mathrm{C}$.

\subsection{Moisture and ash content}

To obtain the moisture content, porcelain crucibles, in triplicate, were placed in the oven at $100{ }^{\circ} \mathrm{C}$ for 2 hours. Subsequently, after cooling in a desiccator, they were weighed and $1 \mathrm{~g}$ of fresh fungal mycelium was added to each crucible, taken to the oven at $105{ }^{\circ} \mathrm{C}$ for 3 hours. After cooling in a desiccator, successive weighings were carried out until constant weight was obtained (Brasil 2020). The humidity value was obtained by applying the Formula 1:

Formula 1 - Moisture value obtained from the mycelium of Diplodia pinea

$$
\text { Moisture }(\%)=(\mathrm{Pu}-\mathrm{Ps}) / \mathrm{Pa} \mathrm{X} 100
$$

Note Pa: sample weight; Pu: sample weight + crucible weight; Ps: crucible weight + sample after desiccation weight.

To obtain the ash content, crucibles of known weight, in triplicate, containing $1 \mathrm{~g}$ of sample, were kept for $6 \mathrm{~h}$ in a muffle furnace at $600{ }^{\circ} \mathrm{C}$ until complete incineration of the organic matter. After cooling in a desiccator, they were weighed again and the ash content was calculated according to the following Formula 2 (Brasil 2020).

Formula 2 - Ash value obtained from the mycelium of Diplodia pinea

Ashes $(\%)=\mathrm{N} / \mathrm{P} \times 100$

Note: N: ash weight; P: sample weight. 


\subsection{Production of extracts}

The extracts were produced using the modified Soxhlet apparatus (Patent INPI number 0601703-7). It was started with $30 \mathrm{~g}$ of lyophilized mycelium and hexane, chloroform, ethyl acetate, methanol, and a 50\% hydroethanolic mixture (1:1) were used in an increasing polarity sequence (Carvalho et al., 2009). Each solvent was in contact with the sample for three cycles of $10 \mathrm{~h}$. The extracts were obtained by evaporating the solvent in a water bath at $40{ }^{\circ} \mathrm{C}$ until dry and named: hexane mycelium extract (HEM), mycelium chloroform extract (ECM), mycelium ethyl acetate extract (EAEM), mycelium methanol extract (EMM), and mycelium ethanol/water extract (EMEA).

\subsection{Obtaining the crystal}

During the obtaining of the EMM, a precipitate was formed in the extraction flask, initially called IS2, and crystallization was carried out using 5 drops of distilled water and $1 \mathrm{~mL}$ of methanol. After drying at room temperature, a needle-shaped crystal was obtained, which was identified by monocrystal X-ray diffractometry (Rech et al., 2020 adapted from).

\subsection{Thin Layer Chromatography (TLC)}

The IS2 samples, commercial standard glucose, macerated lyophilized fungal mycelium (MFL), culture medium (MC), and the culture medium extract (EMC), using the modified Soxhlet, were tested using the TLC technique. These were initially diluted in distilled water and applied in the stationary phase (Whatman ${ }^{\circledR}$ silica gel chromatoplates) with the aid of a capillary. The mobile phase used for carbohydrate detection was ethyl acetate: propanol: acetic acid: water in a 4:2:2:1 $(v / v / v / v)$ ratio using $1 \%$ orcinol as a developer (Andrade et al., 2010).

\subsection{Monocrystal X-ray Diffraction}

For the identification of the IS2 crystal by the Monocrystal X-Ray Diffractometry (DRXM) technique. This analysis was performed at the Single-crystal X-Ray Diffraction Laboratory, Department of Chemistry of UFPR. The unit cell data were collected using a Bruker - D8 Venture diffractometer equipped with a Photon 100 CMOS area detector, two sources of monochromatic radiation of Mo-K $\alpha(\lambda=0,7107 \AA)$ and $\mathrm{Cu}-\mathrm{K} \alpha(\lambda=1,5418 \AA)$, and Kryoflex II device, for collecting samples at low temperature. The analysis was carried out at $300 \mathrm{~K}$ using the $\mathrm{Cu}-\mathrm{K} \alpha$ font source. For the analysis, a crystalline fragment was selected from a portion of crystals immersed in mineral oil, which was carefully transferred to a micro-mount that was fixed on the diffractometer goniometer. The data were processed using the APEX3 program. The unit cell parameters found were compared with literature data using the CCDC database (Cambridge Crystallographic Data Center) (Rech et al., 2020 adapted from).

\section{Results and Discussion}

\subsection{In vitro production of fungus}

A yield of approximately $0.9 \mathrm{~g}$ of fresh mycelium, $0.4 \mathrm{~g}$ after drying, and $50 \mathrm{~mL}$ of medium were obtained from each incubated culture flask. D. pinea had a light-colored mycelium at 7 days of cultivation in PD broth. The fungus did not cause turbidity nor change in the odor of the culture medium.

The methodology used in the cultivation of the fungus contributes to less biomass production for 7 days, is considered a short incubation time when the objective is to produce mycelium in greater quantity. The absence of aeration and 
the use of bioreactors, as well as the low temperature, are stressors, which also decreased mycelial production (Andrade et al., 2010).

Diplodia pinea is one of the main pathogens of conifers, with a wide worldwide distribution, studied for the ability to infect in all stages of tree development (Stanosz et al., 1999). However, studies related to the search for secondary metabolites and biological activities are still scarce. Wada and Ishida, 1979 characterized molecules belonging to the class of pentacetides, which may have antifungal action to the D. pinea specie (Wada and Ishida 1979). A pentacetide produced by Fusarium sp. in liquid culture showed potent antifungal activity against Candida albicans (Brady and Clardy 2000). Besides, Liu et al., 2019 found two new terpenoids (pentanortriterpenoid,23,24,25,26,27-pentanorlanost-7,9(11)-dien-33,22-diol, and triterpenoid, lanost-8-en-3 $\beta, 22 \mathrm{~S}, 23 \mathrm{~S}$-triol), which were characterized by the species Diplodia cupressi with sensitive inhibition of tumor cell growth in vitro. This scarcity of reports of molecules arising from fungal metabolism of the genus Diplodia is possibly linked to the complexity of the molecular structure, conditions of obtaining, and consequently structural clarification (Brady and Clardy 2000).

\subsection{Moisture and Ash Content}

The analysis of humidity and ash is useful for quality control of a sample, indications of impurities in it, comparison with the literature of previously obtained results, or description of these two physical-chemical contents when they are not yet included in a certain sample (Araújo et al., 2006). They are used as quality control for edible plants and fungi. When evaluating the use of this test for phytopathogenic microorganisms, there is a great absence of reports and studies published in this regard, with some studies reporting an increase in the moisture content of a plant, given the presence of a fungus as described by Ullah et al., 2016. Therefore, this test was carried out to collaborate with the physicochemical description of phytopathogenic fungi, suggesting a simple and standardized parameter for controlling crop purity.

The moisture content for the fungal mycelium was $96.4 \%$ (standard deviation $-S D \pm 0.04)$ and $0.2 \%(S D \pm 0.09)$ for ash indicating a large percentage of water retained in the mycelium. In comparison with published studies for other fungi, ash content ranging from 3.5 to $12 \%$ is observed (Kalac 2009). For moisture content, Barber, 2019 observed $85 \%$ humidity in a food parasitized by a fungus. It is noteworthy that no value references were found for phytopathogenic fungi produced in vitro under stress conditions

\subsection{Production of extracts}

Different yields were obtained for each extract. In this study, only the yield of the methanol extract (47.3\%) was reported, which was obtained from the metabolite in question.

\subsection{Obtaining the Crystal}

From the methanol extract, a crystal (IS2 - $120 \mathrm{mg}$ ) was obtained in the form of needles, refractable to light-colored light.

The monocrystal X-ray diffractometry (crystallography) technique is an accurate method of non-destructive structural characterization, providing structural parameters such as specific connection angles and structural arrangement of a molecule (Banaciu et al., 2015). Thus, it is considered that this technique is capable of evaluating its perfect atomic and structural arrangement. 


\subsection{Thin Layer Chromatography (TLC)}

The TLC analysis showed positivity for the substance D-mannitol only in the lyophilized fungal mycelium (MFL), before going through the extraction process, with the retention factor (RF) of the IS2 crystal (0.58) equal to that obtained for the MFL sample.

This screening by TLC was carried out to prove that the presence of the isolated D-mannitol occurs during mycelial growth, being produced in vitro by the fungus. As the same result was not obtained for the MC and EMC samples, it is proved that the Soxhlet equipment and the temperature employed did not influence the production of this metabolite.

\subsection{Monocrystal X-ray Diffraction}

The unit cell parameters of the IS2 isolate can be seen in Table 1. According to the spatial arrangement, atoms found and data recorded at The Cambridge Crystallographic Data Center (CCDC) and Fachinformationszentrum Karlsruhe (FIZ), deposit DMANTL02, DMANTL10, DMANTL12, and DMANTL14, the compound can be characterized being D-mannitol (Figure 1).

Table 1 - Unit cell data for the IS2 sample obtained by Monocrystal X-Ray Diffractometry.

\begin{tabular}{l|l}
\hline Crystalline System & Orthorhombic P \\
\hline $\mathbf{A}$ & $5.55 \AA$ \\
\hline $\mathbf{B}$ & $8.69 \AA$ \\
\hline $\mathbf{C}$ & $16.91 \AA$ \\
\hline $\boldsymbol{\alpha}=\boldsymbol{\beta}=\boldsymbol{\gamma}$ & 90 graus \\
\hline Volume & $816 \AA$ \\
\hline
\end{tabular}

Source: Authors (2021).

Figure 1 - Structure of the compound D-mannitol.

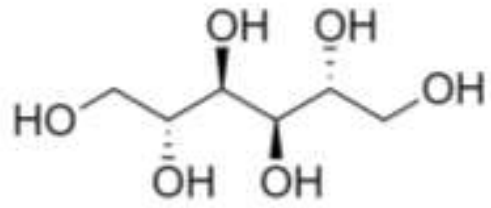

Source: Authors (2021).

D-mannitol (table and figure 1) is a natural carbohydrate found in vegetables, tree exudates, seaweed, with scarcity in the Animal Kingdom (Calmes et al., 2013), obtained by extraction in alcohol under heating. This monosaccharide, although widely distributed, has not been found in abundant amounts in natural sources (Oliveira et al., 2009; Calmes et al., 2013). Among these sources, the most relevant are the mycelia and fungi fruiting bodies, which make the report of new sources of obtaining this product extremely important, such as the description of D-mannitol from D. pinea.

Chemically it is a very versatile molecule with applications in the pharmaceutical industry, as an excipient; in the food industry as an adjuvant improving the taste of some products and in the medical field for being an osmotic diuretic. Due to its chemical conformation, it can be used in the synthesis of several chiral ligands and in organic synthesis for the construction of chiral blocks applied to obtain several enantiomerically pure compounds. Examples of molecules synthesized 
using D-mannitol include micalamide A (antitumor, antiviral and immunosuppressive), clavulazine (antimicrobial and herbicide) and longimycin C (antitumor) (Oliveira et al., 2009).

Calmes et al., 2013, evaluated the increased production of mannitol by the necrotrophic fungus Alternaria brassicicola in different periods of stress; concluding that the production of this carbohydrate is linked to the maintenance of its life cycle and emphasizing that this metabolite has demonstrated important functions in the energy reserve, regeneration of $\mathrm{NADPH}$, in morphogenesis, conidiation and spore development, maintenance, and resistance. It is very important in pathogenesis because it is used to suppress the resistance of plants, observing that their production increases in the face of environmental stress and the infection process (Calmes et al., 2013; Meena et al., 2015). In a previous study, Moura, 2017 observed that under different conditions of cultivation $\left(20^{\circ} \mathrm{C}, 21\right.$ days), there was no significant production of this metabolite (Moura 2017). In stressful conditions of decreasing temperature and incubation time, we can see that the fungus started to synthesize the carbohydrate, thus optimizing the production of the metabolite.

In the study described by Calmes et al., 2013 it was proposed that the metabolism of mannitol in fungi occurs through the action of mannitol-1-phosphate 5-dehydrogenase, which reduces fructose 6-phosphate in mannitol-1-phosphate using NADH as a cofactor; then dephosphorylation by a mannitol-1-phosphate phosphatase, resulting in inorganic phosphate and mannitol (Calmes et al., 2013). In addition, Dulermo et al., 2010 reported in their study with the fungus Botrytis cinerea, an alternative route suggesting that mannitol would be metabolized by the enzyme mannitol-1-phosphate by phosphorylation (Dulermo et al., 2010).

For fungi of the genus Diplodia, markers were found that indicate the presence of isoenzymes in the different morphotypes of $D$. pinea, and among these, we can mention beta glycosidase and glucose phosphate isomerase (Stanosz et al., 1999). These enzymes can catalyze reactions that lead to the formation of D-mannitol. In Diplodia viticola, the carbohydrates mannitol and arabitol in mycelium were found, whose biosynthesis capacity was the first described for the genus, in addition to the enzymes mannitol dehydrogenase and glucose-6-phosphate dehydrogenase as involved in the production of mannitol (Strobel and Kosuge 1965). For the fungus D. pinea, the present work brings the first description of this metabolite in this species and the second description in the whole genus.

\section{Conclusion}

The fungus D. pinea was able to produce the metabolite D-mannitol, besides it was reported in this species for the first time. Regarding to moisture and ash Content, it was observed a high humidity value and a low ash value, data that were considered important due to the scarcity of related articles for other phytopathogenic fungi. Due to the worldwide demand for the search of substances with potential biological activity, safety, and sustainable potential, D. pinea might be considered a good option for biotechnological use in the production of metabolites, in addition to contributing to the research of substances of potential use from phytopathogens.

The present study allowed the knowledge of physical and chemical characteristics of the fungus D. pinea, previously not reported for this species and isolated. It was also possible to obtain an isolate characterized as a metabolite of great applicability, which was described for the first time in the species and the second time in the genus, using a highly accurate methodology for identifying chemical molecules. Therefore, it can be observed that the fungus was promising, which corroborates research in the chemical area of fungi, a field of great interest that is on the rise, but which is still poorly studied. The authors suggest continuing research and conducting other tests such as biological activity for this fungus to expand research at the biotechnological level. 


\section{Acknowledgments}

This work was carried out with the support of the Coordination of Improvement of Higher Education Personnel Brazil (CAPES) - Financing Code 001. The authors are grateful to EMBRAPA Florestas, CNPq and Universidade Federal do Paraná for the financial support and fellowships. On behalf of all authors, the corresponding author states that there is no conflict of interest.

\section{References}

Andrade, M. C. N., Chavari, J. L., Minhoni, M. T. A., Zied, D. C. (2010). In vitro mycelium growth of five Agaricus bisporus strains submitted to different temperature conditions. Acta Scientiarum Agronomy. DOI: https://doi.org/10.4025/actasciagron.v32i1.33310.4025/actasciagron.v32i1.333

Appelt, H. R., Oliveira, J. S., Santos, R. C. V., Rodrigues, O. E. D., Santos, M. Z., Heck, E. F., Rosa, L. C. (2013). Synthesis and Antimicrobial Activity of Carbohydrate Based Schiff Bases: Importance of Sugar Moiety. Journal of Carbohydrate Chemistry article ID 320892. DOI: 10.1155/2013/320892.

Araújo, A. A. S., Mercuri, L. P., Seixas, S. R. S., Storpirtis, S., Matos, J. R. (2006). Determinação dos teores de umidade e cinzas de amostras comerciais de guaraná utilizando métodos convencionais e análise térmica. Brazilian Journal of Pharmaceutical Sciences. DOI: https://doi.org/10.1590/S151693322006000200013.

Banaciu, A. A., Udriştioiu, E. G., Boul-Enein, H. Y. (2015). X-Ray Diffraction: Instrumentation and Applications. Critical Reviews in Analytical Chemistry. DOI: $10.1080 / 10408347.2014 .949616$

Barber, L. (2019). Studies on The Nutrient Quality and Mycoflora of Citrus Paradisi Sold in Port Harcourt Rivers State Nigeria. Journal of Environmental Science, Toxicology and Food Technology. DOI: 10.9790/2402-1305029194.

Brady, S. F and Clardy J. (2000). CR377, A new pentaketide antifungal agent isolated from an endophytic fungus. Journal of Natural Products. DOI: https://doi.org/10.1021/np990568p.

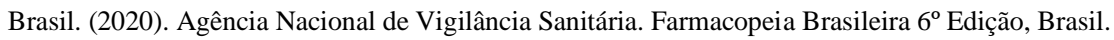

Bubb W. A. (2003). NMR Spectroscopy in the Study of Carbohydrates: Characterizing the Structural Complexity. Wiley Periodicals, Inc Concepts in Magnetic Resonance Part A. DOI 10.1002/cmr.a.10080.

Calmes, B., Guillemette, T., Teyssier, L., Siegler, B., Pigné, S., Landreau, A., Iacomi, B., Lemoine, R., Richomme, P., Simoneau, P. (2013). Role of mannitol metabolism in the pathogenicity of the necrotrophic fungus Alternaria brassicicola. Frontiers in Plant Science. DOI: https://doi.org/10.3389/fpls.2013.00131.

Carvalho, J. L. S., Cunico, M. M., Dias, J. F. G., Miguel, M. D., Miguel, O. G. (2009). Termoestabilidade de processos extrativos de Nasturtium officinale R. Br., Brassicaceae por sistema de Soxhlet modificado. Quimica Nova. DOI: https://doi.org/10.1590/S0100-40422009000400034.

Dulermo, T., Rascle, C., Billon-Grand, G., Gout, E., Bligny, R., Cotton, P. (2010). Novel insights into mannitol metabolism in the fungal plant pathogen Botrytis cinerea. Biochemical Journal. DOI: 10.1042/BJ20091813.

Fontan, J. S., Amadio, M. B. (2015). O uso do carboidrato antes da atividade física como recurso ergogênico: Revisão Sistemática. Revista Brasileira de Medicina e do Esporte. DOI: 10.1590/1517-86922015210201933.

Kalac, P. (2009). Chemical composition and nutritional value of European species of wild growing mushrooms: A review. Food Chemistry. DOI: 10.1016/j.foodchem.2008.07.077.

Kusari, S., Pandey, S.P., Spiteller, M. (2013). Untapped mutualistic paradigms linking host plant and endophytic fungalproduction of similar bioactive secondary metabolites. Phytochemistry. DOI: 10.1016/j.phytochem.2012.07.021.

Liu, X-Y., Wang, X-L., Shen, T., Ren, D-M., Lou, H-X., Wang, X-N. (2019). Two new triterpenoids from the fungus Diplodia cupressi. Natural Product Research. DOI: https://doi.org/10.1080/14786419.2019.1578762.

Meena, M., Prasad, V., Zehra, A., Gupta, V. K., Upadhyay, R. S. (2015). Mannitol metabolism during pathogenic fungal-host interactions under stressed conditions. Frontiers in Plant Science. DOI: https://doi.org/10.3389/fmicb.2015.01019.

Moura, P. F, 2017. Caracterização e otimização dos métodos de cultivo dos fungos Armillaria sp., Botrytis cinerea e Diplodia pinea, estudo químico e avaliação das atividades biológicas de extratos de Diplodia pinea [Dissertation]. Curitiba (PR): University Federal do Paraná.

Oliveira, P. S. M., Ferreira, V. F., Souza, M. V. (2009). Utilização do D-manitol em síntese orgânica. Química Nova. DOI: 10.1590/S010040422009000200031 .

Pinto, A. C., Silva, D. H. S., Bolzani, V. S., Lopes, N. P., Epifanio, R. A. (2002). Produtos naturais: atualidades, desafios e perspectivas. Química Nova. DOI: $10.1590 / \mathrm{S} 0100-40422002000800009$.

Rani, R., Sharma, D., Chaturvedi, M., Yadav, J. P. (2017). Antibacterial activity of twenty diferente endophytic fungi isolated from Calotropis procera and time kill assay. Journal of Clinical Microbiology. DOI:10.4172/2327-5073.1000280.

Reglinski, T., Taylor, J. T, Ah Chee, A., Northcott, G., Spiers, M. (2013). Biochemical responses to ultraviolet-C radiation and methyl jasmonate in Pinus radiata seedlings that accompany induced resistance to Diplodia pinea. Plant Pathology. DOI: https://doi.org/10.1111/ppa.12008. 
Research, Society and Development, v. 10, n. 7, e28110716424, 2021

(CC BY 4.0) | ISSN 2525-3409 | DOI: http://dx.doi.org/10.33448/rsd-v10i7.16424

Rech, K. S., Oliveira, C. F., Moura, P. F., Oliveira, C. S. P., Hirota, B. C. K., Oliveira, M., Rüdiger, A. L., Sá, E. L., Miguel, O. G., Auer, C. G., Miguel, M. D. Optimisation of Bjerkandera adusta culture conditions for the production of $\alpha$ - $\alpha$-trehalose. Natural Product Research. DOI: https://doi.org/10.1080/14786419.2020.1758092

Silva, F. B., Mazarotto, E. J., Santos, A. F., Auer, C. G. (2018). Caracterização morfológica, fisiológica e patogênica de isolados de Armillaria sp. da Região Sul do Brasil. Summa Phytopathologica. DOI: https://doi.org/10.1590/0100-5405/175653.

Smith, D. R., Stanosz, G. R., Albers, J. (2014). Detection of the Diplodia shoot blight and canker pathogens from red and jack pine seeds using cultural methods. Canadian Journal of Plant Pathology. DOI: https://doi.org/10.1080/07060661.2014.971874.

Stanosz, G. R., Swart, W. J., Smith, D. R. (1999). RAPD marker and isozyme characterization of Sphaeropsis sapinea from diverse coniferous hosts and locations. Mycological Research. DOI: https://doi.org/10.1017/S0953756299008382.

StrobeL, G. A., Kosuge, T. (1965). Polyol metabolism in Diplodia viticola Desm. Archives of Biochemistry and Bbiophysics. DOI:10.1016/0003 9861(65)90409-1.

Ullah, H., Alam, S., Shah, H. M., Ullah, M., Zeb, A., Kamaran, S., Sami, A. (2016). Analysis of physicochemical attributes of potato lines infected with Rhizoctonia solani. International Journal of Biosciences. DOI: http://dx.doi.org/10.12692/ijb/9.1.415-420.

Wada, K., Ishida, T. (1979). A Steroid hydroxylase Inhibitor, diplodialide-A, and related metabolites from Diplodia pinea. Journal of the Chemical Society, Perkins Transactions Royal Society of Chemistry. DOI:10.1039/p19790001154.

Yunes, R. A., Calixto, J. B. (2001). Plantas Medicinais Sob a Ótica da Química Moderna, Brasil. 1 Ed. Chapecó: Argos Editora Universitária, 523 p. 